\title{
COMPARISON OF PROPOFOL-NALBUPHINE AND PROPOFOL -FENTANYL COMBINATIONS IN TOTAL INTRAVENOUS ANAESTHESIA
}

\section{Kanhaiya Lal Kishnani*}

\section{Satyajeet Singh}

\section{Sanjay. P. Dave}

Associate Professor,Department of Anaesthesiology, Peoples College of Medical Sciences and Research Centre, Bhanpur Bhopal. *Corresponding Author

Junior Resident, Department of Anaesthesiology, Peoples College of Medical Sciences and Research Centre, Bhanpur Bhopal.

Professor and HOD, Department of Anaesthesiology, Peoples College of Medical Sciences and Research Centre, Bhanpur Bhopal.

ABSTRACT

Introduction: Use of Total Intravenous Anaesthesia (TIVA) has increased in recent past. It has become method of choice in Day Care Surgery practice. G.A. with inhalational agents requires specific vaporizers for different inhalational agents. These vaporisers require costly periodic maintenance and calibration.

Material And Methods: Total 100 patients between age of 30 and 65 years belonging to ASA grade I and II under- going surgery up to $90 \mathrm{~min}$ duration were included. The patients were divided into two groups each of 50 patients. Patients in group $A$ received Nalbuphine $0.2 \mathrm{mg} / \mathrm{Kg}$ body weight IV and patients in group B received Inj. Fentanyl $2 \mathrm{~g} / \mathrm{Kg}$ body weight IV, $5 \mathrm{~min}$ before induction.

Patients were induced with Propofol $2 \mathrm{mg} / \mathrm{kg}$ body weight and Inj. Vecuronium $0.1 \mathrm{mg} / \mathrm{kg}$ body weight. All patients were intubated. Maintenance of Anaesthesia was done with Propofol infusion. Patients were ventilated with controlled ventilation, breathing circuit attached to circle absorber. Vital parameters were monitored. Residual neuro-muscular paralysis was reversed with Inj. Neostigmine and Inj. Glycopyrolate intravenously.

Results: Initially reduction was observed in pulse rate and blood pressure in both groups followed by elevation. Rise from basic level was similar in both groups. Subsequent rise was more in Fentanyl group throughout the procedure while it came down to near base level in Nalbuphine group. At the end of procedure elevation of SBP and DBP was seen more in Fentanyl group. The First rescue analgesic requirement was earlier in Fentanyl group. Nausea, Shivering, Respiratory Depression and Sedation were more in Fentanyl group in postoperative period.

Conclusion: Nalbuphine provided comparatively better hemodynamic stability and excellent post operative analgesia. Nausea, vomiting and sedation were less with Nalbuphine. The induction was found to be smooth in both groups. Recovery from anaesthesia was early in Nalbuphine group.

\section{KEYWORDS : Propofol, Nalbuphine, Fentanyl, Total Intravenous Anaesthesia}

\section{INTRODUCTION}

Use of TIVA has increased in recent past due to smooth induction, stable operating conditions, easiness in control of anaesthesia, smooth recovery, comparatively lower cost than G.A with inhalational agents and no pollution of O.T. area. Availability of better newer drugs with minimum cardiac depressant effects, lesser Nausea and Vomiting in post operative period (PONV), easiness to control anaesthesia and smooth recovery has made TIVA method of choice for induction and maintenance of anaesthesia.

Before advent of TIVA, all surgical procedures were being performed under GA with inhalational anaesthetic agents. Specific vaporizers are required for different inhalational agents; they require periodic costly calibration and maintenance. Release of exhaled anaesthetic gases produce pollution of O.T. environment.

Purpose of this study was to compare hemodynamic response and analgesic effect of two drug combinations using (1) Propofol--Nalbuphine and (2) Propofol- Fentanyl in induction for TIVA. Maintenance, recovery characteristics and side effects were also studied.

\section{MATERIAL AND METHODS}

Total 100 adult patients between age of 30 and 65 years belonging to ASA I and II of either sex under-going surgical procedures lasting up to $90 \mathrm{~min}$ duration were included in the study. The patients were divided into two groups of 50 patients each. Patients taken for procedure at odd serial no. 1, 3, 5.... of 100 patients, received Nalbuphine $0.2 \mathrm{mg} / \mathrm{Kg}$ body weight I/V (Group A) and patients taken for surgery at even serial no. $2,4,6 \ldots . .$. of 100 patients received Inj. Fentanyl $2 \mu \mathrm{g} / \mathrm{Kg}$ body weight I/V (Group B), 5 min before induction.

Patients with previous history of hypersensitivity to any of study drugs, allergy to egg or fat, on long term Phenothiazines and MAO Inhibitors treatment, anticipated difficult intubation, patients with significant systemic diseases like cardiovascular, renal, hepatic diseases, thyroid disease, neurological disorders, $\mathrm{H} / \mathrm{O}$ Bronchial asthma and other respiratory diseases, $\mathrm{H} / \mathrm{O}$ seizure disorders, $\mathrm{H} / \mathrm{O}$ opium addiction, Alcohol abuse, recent $\mathrm{H} / \mathrm{O}$ head injury, pregnant women and patients who did not give consent were excluded One capsule of Omeprazole $20 \mathrm{mgs}$ and one tablet of Alprazolam $0.25 \mathrm{mg}$ were given at 10.00 PM in previous night of procedure.

All patients were pre-loaded with Lactated Ringer's solution ( $15 \mathrm{ml} / \mathrm{kg}$ Body weight). ECG, pulse oximetery probe and NIBP cuff were attached when patient came in O.T. Vital parameters like heart rate, $\mathrm{SpO} 2$ and NIBP were recorded as base line.

Patient were induced with Propofol $2 \mathrm{mg} / \mathrm{kg}$ body weight and Inj. Vecuronium $0.1 \mathrm{mg} / \mathrm{kg}$ followed by bag mask ventilation with $\mathrm{O} 2$ and $\mathrm{N} 2 \mathrm{O}$ for 3 minutes. All patients were intubated with appropriate size endo-tracheal tube.

Vital parameters were recorded at time of induction, 1,3,5 min and at 5 min intervals for initial $20 \mathrm{~min}$ of induction and then at every 10 min intervals till completion of surgery.

Maintenance of Anaesthesia was done with I/V infusion of Propofol at rate of $10 \mathrm{mg} / \mathrm{kg}$ body weight/hour for first $10 \mathrm{~min}$, $08 \mathrm{mg} / \mathrm{kg}$ body weight/hour for next $10 \mathrm{~min}$ and $06 \mathrm{mg} / \mathrm{Kg}$ body weight/hour for remaining duration. Inj. Vecuronium 0.015 $\mathrm{mg} / \mathrm{Kg}$ Body weight was given every 20 to $40 \mathrm{~min}$. All patients 
were ventilated with $\mathrm{O} 2$ and $\mathrm{N} 2 \mathrm{O}$, controlled ventilation and breathing circuit attached to circle absorber. Supplemental dose of $25 \mathrm{mg}$ of Propofol was planned to be given during surgical procedure if required.

For fluid resuscitation during operation I.V. Ringer Lactated fluid was given. This was calculated as per following criteria: First $10 \mathrm{~kg}$ of body weight $4 \mathrm{ml} / \mathrm{kg}$, second $10 \mathrm{~kg}$ of body weight $2 \mathrm{ml} / \mathrm{kg}$, remaining body weight $1 \mathrm{ml} / \mathrm{kg}$ body weight. $50 \%$ of this was infused in first hour and remaining $50 \%$ in second hour. Residual neuro-muscular block was reversed with Inj. Neostigmine $0.05 \mathrm{mg} / \mathrm{kg}$ body weight and Inj. Glycopyrolate $0.008 \mathrm{mg} / \mathrm{kg}$ body Wt. intravenously at the end of surgery.

Patients were observed in post operative period for vital parameters, untoward symptoms and signs like respiratory depression, pruritus, nausea, vomiting, sedation and shivering.

\section{RESULT}

Both groups were comparable in demographic characteristics in respect of age, weight, male-female gender ratio and duration of surgery. The pulse rate and blood pressure showed slight reduction after receiving drugs. They showed elevation at the time of induction in both groups. This initial rise in heart rate and B.P. from basic rate was almost similar in both groups. Rise was found subsequently throughout the procedure also in both groups and was observed more in Fentanyl group than in Nalbuphine group. Pulse rate increased up to $20 \%$ from base level in Fentanyl group and up to $10 \%$ in Nalbuphine group. This rise returned to near base level in Nalbuphine group. Elevation of SBP and DBP was observed again at the end of procedure. It was more in Fentanyl than in Nalbuphine group.

The induction was smooth in both groups.

No patient required supplemental dose of Propofol during surgery in both group. The requirement of rescue analgesic was earlier in Fentanyl than in Nalbuphine group (100.36 Minutes Vs 135.60 Minutes after initial dose). Nausea, Shivering and Respiratory Depression (fall in SpO2 below $90 \%$ with room air) in post operative recovery was observed more in Fentanyl group. In Fentanyl group 10\% patients were found to have sedation, while no patient in Nalbuphine group showed signs of sedation. Recovery from anaesthesia was early and smooth in Nalbuphine group.

Table 1 Demographic Characteristics

\begin{tabular}{|c|c|c|c|c|}
\hline \multirow{3}{*}{ Age (Yrs) } & \multicolumn{2}{|c|}{ Group A (Nalbuphine) } & \multicolumn{2}{|c|}{ Group B(Fentanyl) } \\
\hline & Mean & SD & Mean & SD \\
\hline & 45.93 & 15.68 & 42.7 & 17.06 \\
\hline Weight $(\mathrm{Kg})$ & 61.27 & 9.9 & 63.37 & 13.36 \\
\hline $\begin{array}{l}\text { Duration of procedure } \\
\text { (min) }\end{array}$ & 85 & 12.52 & 82 & 13.68 \\
\hline Gender M/F (\%) & $20 / 80$ & & $16 / 84$ & \\
\hline
\end{tabular}

Table 2 Percentage Change Of Pulse Rate At Different Stages Of Anaesthesia

\begin{tabular}{|l|l|l|}
\hline & $\begin{array}{l}\text { Group A } \\
\text { (Nalbuphine) }\end{array}$ & $\begin{array}{l}\text { Group B } \\
\text { (Fentanyl) }\end{array}$ \\
\hline Before Induction & 5 & 5 \\
\hline During Induction & 10 & 20 \\
\hline 1 min After intubation & 8 & 20 \\
\hline 3 min after induction & 5 & 10 \\
\hline 5 min after induction & 5 & 10 \\
\hline 10 min after induction & 5 & 08 \\
\hline 15 min after induction & 7 & 12 \\
\hline 20 min after induction & 5 & 15 \\
\hline 30 min after induction & 08 & 15 \\
\hline 40 min after induction & 08 & 16 \\
\hline
\end{tabular}

50 min after induction

60 min after induction

70 min after induction

80 min after induction

90 min after induction

Table 3 Changes In Mean Systolic Blood Pressure (SBP)

\begin{tabular}{|l|l|l|l|l|}
\hline & \multicolumn{2}{|l|}{$\begin{array}{l}\text { Group A } \\
\text { (Nalbuphine) }\end{array}$} & \multicolumn{2}{c|}{$\begin{array}{l}\text { Group B } \\
\text { (Fentanyl) }\end{array}$} \\
\hline & $\begin{array}{l}\text { Mean } \\
\text { (mm of } \\
\text { Hg) }\end{array}$ & $\begin{array}{l}\text { change } \\
\text { from } \\
\text { base line }\end{array}$ & $\begin{array}{l}\text { Mean } \\
\text { (mm of } \\
\text { Hg) }\end{array}$ & $\begin{array}{l}\% \\
\text { change } \\
\text { from } \\
\text { base line }\end{array}$ \\
\hline Base line & 118.10 & & 123.53 & \\
\hline 3 Min after drug & 110.05 & 6.81 & 115.50 & 6.50 \\
\hline $\begin{array}{l}\text { During Laryngoscopy } \\
\text { \& Intubation }\end{array}$ & 125.84 & 6.56 & 128.58 & 4.08 \\
\hline 1 Min after intubation & 123.43 & 4.5 & 129.45 & 4.8 \\
\hline 3 Min after intubation & 122.83 & 4.01 & 127.52 & 4.04 \\
\hline 5 Min after intubation & 123.10 & 4.24 & 129.02 & 4.45 \\
\hline 10 Min after intubation & 122.35 & 3.6 & 129.89 & 5.15 \\
\hline 15 Min after intubation & 123.41 & 4.5 & 130.32 & 5.5 \\
\hline 20 Min after intubation & 119.96 & 1.58 & 131.12 & 6.15 \\
\hline 30 Min after intubation & 119.81 & 1.45 & 131.63 & 6.56 \\
\hline 40 Min after intubation & 121.12 & 2.56 & 136.45 & 10.46 \\
\hline 50 Min after intubation & 120.46 & 2.83 & 136.38 & 10.28 \\
\hline 60 Min after intubation & 119.60 & 1.8 & 132.36 & 7.06 \\
\hline 70 Min after intubation & 121.50 & 4.08 & 134.12 & 8.47 \\
\hline 80 Min after intubation & 122.48 & 5.01 & 132.6 & 7.25 \\
\hline 90 Min after intubation & 122.60 & 5.4 & 134.76 & 8.98 \\
\hline
\end{tabular}

Table 4 Changes In Mean Diastolic Blood Pressure (DBP)

\begin{tabular}{|l|l|l|l|l|}
\hline Time & \multicolumn{2}{|l|}{$\begin{array}{l}\text { Group A } \\
\text { (Nalbuphine) }\end{array}$} & \multicolumn{2}{l|}{$\begin{array}{l}\text { Group B } \\
\text { (Fentanyl) }\end{array}$} \\
\hline & $\begin{array}{l}\text { Mean } \\
\text { (mm of } \\
\text { Hg) }\end{array}$ & $\begin{array}{l}\text { change } \\
\text { from } \\
\text { base line }\end{array}$ & $\begin{array}{l}\text { Mean } \\
\text { (mm of } \\
\text { Hg) }\end{array}$ & $\begin{array}{l}\text { change } \\
\text { from } \\
\text { base line }\end{array}$ \\
\hline Base line & 78.0 & & 76.0 & \\
\hline 3 Min after intubation & 72.7 & 6.80 & 80.94 & 6.50 \\
\hline $\begin{array}{l}\text { During Laryngoscopy } \\
\text { \& intubation }\end{array}$ & 82.96 & 6.36 & 79.86 & 5.08 \\
\hline 1 Min after intubation & 81.43 & 4.4 & 79.95 & 5.2 \\
\hline 3 Min after intubation & 81.23 & 4.15 & 79.60 & 4.74 \\
\hline 5 Min after intubation & 81.32 & 4.14 & 79.34 & 4.40 \\
\hline 10 Min after intubation & 80.96 & 3.8 & 79.87 & 5.10 \\
\hline 15 Min after intubation & 81.70 & 4.75 & 80.21 & 5.55 \\
\hline 20 Min after intubation & 79.03 & 1.38 & 80.59 & 6.05 \\
\hline 30 Min after intubation & 79.20 & 1.55 & 80.22 & 5.56 \\
\hline 40 Min after intubation & 79.95 & 2.50 & 80.90 & 6.46 \\
\hline 50 Min after intubation & 80.60 & 3.33 & 81.56 & 7.28 \\
\hline 60 Min after intubation & 80.55 & 3.26 & 80.78 & 6.26 \\
\hline 70 Min after intubation & 80.90 & 3.71 & 80.88 & 6.39 \\
\hline 80 Min after intubation & 79.90 & 2.43 & 80.46 & 5.84 \\
\hline 90 Min after intubation & 80.94 & 3.76 & 81.24 & 6.86 \\
\hline
\end{tabular}

\section{Table 5}

First Analgesic dose requirement time after initial dose (VAS based )

\begin{tabular}{|l|ll|}
\hline Group A & (Nalbuphine) & 135.60 Minutes \\
\hline Group B & (Fentanyl) & 100.36 Minutes \\
\hline
\end{tabular}

Table 6 Supplemental Dose Requirement And Untoward Symptoms..

\begin{tabular}{|l|l|l|}
\hline & $\begin{array}{l}\text { Group A } \\
\text { (Nalbuphine) }\end{array}$ & $\begin{array}{l}\text { Group B } \\
\text { (Fentanyl) }\end{array}$ \\
\hline $\begin{array}{l}\text { Supplemental dose of Propofol } \\
\text { during operation. }\end{array}$ & 0 & 0 \\
\hline Pruritis & $0 \%$ & $10 \%$ \\
\hline $\begin{array}{l}\text { Nausea in post operative recovery } \\
\text { room. }\end{array}$ & $6 \%$ & $30 \%$ \\
\hline
\end{tabular}




\begin{tabular}{|l|l|l|}
\hline $\begin{array}{l}\text { Respiratory Depression (fall in } \\
\text { SpO2 below 90\% without O2 in } \\
\text { post operative period.) }\end{array}$ & $0 \%$ & $5 \%$ \\
\hline Shivering & $10 \%$ & $18 \%$ \\
\hline Sedation & $0 \%$ & $10 \%$ \\
\hline
\end{tabular}

Table 7 Recovery From Anaesthesia

\begin{tabular}{|l|l|l|l|l|}
\hline Parameter & \multicolumn{3}{|l|}{ Group B ( Nalbuphine) } & Group B (Fentanyl) \\
\cline { 2 - 5 } & Mean & SD & Mean & SD \\
\hline $\begin{array}{l}\text { Time of } \\
\text { opening of eyes } \\
\text { on verbal } \\
\text { command from } \\
\text { end of TIVA } \\
\text { (Min) }\end{array}$ & 8.39 & 3.0 & 11.46 & 3.8 \\
$\begin{array}{l}\text { Time duration } \\
\text { of orientation } \\
\text { from end of } \\
\text { TIVA (Min) }\end{array}$ & 19.39 & 5.7 & 23.77 & 7.8 \\
\hline
\end{tabular}

\section{DISCUSSION}

Rise in heart rate and blood pressure are routinely observed during laryngoscopy and intubation due to steep rise in serum catecholamine levels [1, 2]. Various pharmacological agents have been used as adjuvants for blunting these effects [3, 4]. Ultra short acting beta-blocker (Esmolol) and opioids have been tried for blunting cardiovascular changes induced by tracheal intubation [5].

Most serious side effect associated with use of opioids is respiratory depression. Nalbuphine is chemically related to Naloxone. It has ceiling effect of respiratory depression. It is also said to cause less nausea and vomiting compared to Morphine, Pethidine and Pentazocine.[6]. It is cost effective with established safety features. Its comparable analgesic potential to Morphine was demonstrated in the study done by Joseph Yanulevich [7] in 1983.

Nalbuphine also has potential to reverse morphine induced respiratory depression. Hence Nalbuphine is considered to have higher safety profile in comparison to opioids. Analgesic potency of Nalbuphine is equivalent to that of Morphine on milligram basis up to dosage of approximately $30 \mathrm{mg}$. Mark W. Guniona [8] rationales use of mixed agonist-antagonist Nalbuphine in opioid based analgesia in his study.

Zeng Z. et al [9] concluded that Nalbuphne provides better safety than Morphine in their meta-analysis of randomized controlled trials for comparison of analgesic effect and safety of Nalbuphine with Morphine. The side effects like pruritus and respiratory depression are less.

It has been observed by Khan F. $A$ et al that Nalbuphine provides cardiovascular stability and causes less nausea vomiting in TIVA technique. [10, 11]

Fentanyl was introduced in 1960's when Morphine and Pethidine were being used for analgesia during surgeries. Fentanyl's shorter duration of action, lesser respiratory depression and cardiac stability made it standard analgesic replacing Morphine and Pethidine in post operative period [12]. Muhammed Ahsan[13] compared Nalbuphine with placebo and observed that placebo group showed enhanced haemodynamic response in comparison to Nalbuphine group. Khan [14] compared Nalbuphine with Fentanyl and documented $25 \%$ rise in heart rate after intubation in the Nalbuphine group in comparison to Fentanyl group. There was no rise in MAP after endotracheal intubation in his study He noticed comparable incidence of nausea and vomiting with both drugs. Duration of analgesia was shorter in Fentanyl than Nalbuphine group ( 37 minutes vs. 62 minutes). The time required for first analgesic dose was shorter in Fentanyl group than in Nalbuphine group in our study also. Rise in heart rate and incidence of nausea were more in Fentanyl group in immediate post operative period in our study.

Weiss et al (15) studied Fentanyl and Nalbuphine in Coronary Artery Bypass Surgery, all patients were given Nalbuphine during and after intubation. Only one patient received Fentanyl and this patient required Nitroglycerine to control MAP. N Sharma [16] had compared haemodynamic response of Nalbuphine with Fentanyl and showed no significant increase in SBP, DBP and HR.

Mikita J. Chaudhari [17] compared efficacy of Nalbuphine and Clonidine in preventing hemodynamic response to laryngoscopy and intubation. The results obtained were similar.

Few cases in Fentanyl group showed sedation, pruritus and shivering in our study.

\section{CONCLUSION}

We conclude that Nalbuphine gives better haemodynamic stability; it provides excellent post operative analgesia therefore reduces requirement of analgesic in post operative period in comparison to Fentanyl. It produces less respiratory depression, less nausea, less shivering in post operative recovery period. Nalbuphine is potent analgesic for use in peri-operative period. These features make Nalbuphine ideal analgesic in TIVA.

\section{REFERENCES}

1. Russell WJ, Morris RG, Frewin D B. Changes in plasma catecholamine concentration during endotracheal intubation. Br J Anqesth. 1981; 53:837-9.

2. Fox Elizabeth J, Garry S, Hill Constance H, Villanveva Raymond, King Benton D. Complications Related to the Pressor Response to Endotracheal Intubation. Anesthesiology. 1977; 44:524-25.

3. Lindgren L, Yli Hankala A, Randell T, M Kirvela, M Scheinin, PJ Neuvonen. Haemodynamic and catecholamine responses to induction of anaesthesia and tracheal intubation: comparison between propofol and thiopentone. $\mathrm{Br}$ J Ancesth. 1993; 70:30610.

4. Stoelting RK, Blood pressure and heart rate changes during short duration laryngoscopy for tracheal intubation: influence of viscous or intravenous lignocaine. Anaesthesia Analgesia. 1978; 57:197-199.

5. Feng CK, Chan KH, Liu KN, Or CH, Lee TY. A comparison of lidocaine fentanyl, and esmolol for attenuation of cardiovascular response to laryngoscopy and tracheal intubation [abstract]. Acta Anaesthesiol Sin 1996 Jun; 34:61-7. Erratum in: Acta Ancesthesiol Sin. 1996; 34:172

6. Mudgalkar N, Reddy, Prasad L The effect of Dexmedetomidine versus Esmolol on attenuation of stress response to endotracheal intubation in patients undergoing elective off pump Coronary artery bypass graftine. Perspectives in medical research. 2016; 4:1:23-26.

7. Joseph Yanulevich. Outpatient anesthesia with nalbuphine hydrochloride. AANA Journal August. 1983; 1:395-397.

8. Mark W. Guniona, Anna Maria Marchionnea, b, Corrie T.M. Anderson. Use of the mixed agonist-antagonist nalbuphinein opioid based analgesia. Acute Pain. 2004; 6:29-39.

9. Zheng Zeng, Jianhua Lu, Chang Shu, Yuanli Chen, Tong Guo, Quing-ping Wu, Shang-long Yao, Ping Yin. A Comparision of Nalbuphine with Morphine for Analgesic Effects and Safety: Meta- Analysis of Randomized Controlled Trials. Sci. Rep. 5; 10927 doi:10.1038/srepl0927 (2015)

10. Miller RR Evaluation of nalbuphine hydrochloride. Am J Hosp Pharmacol $1980 ; 37: 942-49$

11. Khan FA, Zaidi A, Kamal RS. Comparison of nalbuphine and buprenorphine in total intravenous anaesthesia. Anaesthesia 1997; 52:1095-1101.

12. Shribman AJ, Smith G, Achola KJ. Cardiovascular and catecholamine response to laryngoscopy with and without tracheal intubation [abstract]. Br Ancesth. 1987; 59:295-9.

13. Muhammed Ahsan, Etizaz Haider Kazmim, Zahid Akhtar Rao N. Nalbuphine prevents haemodynamic response to endotracheal intubation. J Coll Physicians Surg Pak. 2005; 15:668-70.

14. Khan FA, Hameedullah. Comparison of fentanyl and nalbuphine in total intravenous anaesthesia (TIVA). J Pak Med Assoc. 2002; 52:459-65. COMPARISON OF PROPOFOL-NALBUPHINE AND PROPOFOL -FENTANYL COMBINATIONS IN TOTAL INTRAVENOUS ANAESTHESIA 13

15. Weiss BMI, Schmid ER, Gattiker RI. Comparison of nalbuphine and fentany anesthesia for coronary artery bypass surgery. Hemodynamics, hormonal response, and postoperative respiratory depression. Anesth Analg. 1991; 73:521-9.

16. Neha Sharma, Hetal Parikh. A comparative study of hemodynamic responses to intubation: fentanyl versus nalbuphine Gujarat Medical Journal. 2014 69:48-53.

17. Mikita J. Chaudhari, Upasna Bhatia, Neerav Patel, Kirti D Patel. Efficacy of nalbuphine in preventing haemodynamic response to laryngoscopy and intubation in comparison to clonidine. NHL Journal of Medical Sciences. 2015; 4:1:58-65. 